\title{
The Change in the Identity of Karbi Women: The Bygone Days of Duk
}

\author{
Dr. Chintu Ronghangpi \\ Scientist-C, Indian Council of Medical Research, \\ Department of Biotechnology, Bodoland University, Kokrajhar, \\ Assam, India.
}

\begin{abstract}
The Karbi is a hill tribe residing in the state of Assam in the North-Eastern part of India bordering Bhutan and Bangladesh. The total population of the tribe is 441708 as of the Population of India Census 2011. The tribe is mainly distributed in two districts of Assam, namely, Karbi Anglong and West Karbi Anglong and the neighbouring states like Arunachal Pradesh, Meghalaya and Nagaland also including few regions of Bangladesh. The Karbis belongs to Mongoloid race and speak a distinct dialect belonging to Tibeto-Burman, particularly the Kuki-Chin subgroup of languages. They are a patrilineal society and a married woman retains her father's clan after her marriage. The Karbi women have a facial tattoo known as Duk, which have been prevalent since the Burmese invasion in Assam in the $19^{\text {th }}$ century A.D. It was during this time when the invaders started to take the beautiful girls and held them as captives. To look ugly, the young Karbi girls started using a black vertical line from the forehead to the chin to rescue themselves from the cruel act of the invaders. This tattoo have a great significance as the practice is for unique purpose not meant for beauty but it was fear that made them do so. Since then this black line on the face became an identity for Karbi women and the tribe as a whole. Interestingly, for the past two generations this practice have declined and the present Karbi women are free from such tattoo on their face which was not the case earlier when they had no choice but to go through the pain of piercing their skin to look ugly. With this situation in mind, two main objectives have been put forwarded for this paper; a) what have caused the sudden change in their culture? And, b) why have they not stopped the practice right after the fall of the Burmese invasion in Assam? For this study anthropological methods such as in-depth interview, observation and case study were used.
\end{abstract}

Keywords: Culture, Historical, Tattoo, Traditional, Tribe. 